\title{
Fashion lab as a factor of innovation in fashion authoring design
}

\section{Alessandro Mateus Felippe}

Master's Degree, Universidade do Estado de Santa Catarina

Orcid: 0000-0001-6856-3991/ lattes

\section{Sandra Regina Rech}

PhD, Universidade do Estado de Santa Catarina

Orcid: 0000-0002-0062-6914/ lattes

\section{Icléia Silveira}

PhD, Universidade do Estado de Santa Catarina Orcid: 0000-0003-4493-9768/ lattes

\section{Lucas da Rosa}

PhD, Universidade do Estado de Santa Catarina

Orcid: 0000-0002-8429-2754/ lattes 


\title{
Fashion lab as a factor of innovation in fashion authoring design
}

\begin{abstract}
The post-industrial revolution transformations continue to echo in our society, allowing advances in the area of technology, production, and consumption of products in different segments, especially fashion. In view of this, this article proposes to understand, in an initial and conceptual way, the use of space Fashion lab by fashion designer designers. It is considered that the use of this laboratory can qualify the innovation process during the production of new products. In this work, the basic research was used with a descriptive qualitative approach and the theoretical foundation contemplates the concepts of innovation, fab lab, fashion lab, and authorial design. Finally, the research results indicate that the principles of sharing, experimentation, and prototyping corroborate to the innovation in fashion authoring design in fashion labs.
\end{abstract}

Keywords: Fashion Lab. Authorial Design. Innovation. 


\title{
Fashion lab como fator de inovação no design autoral de moda
}

\begin{abstract}
RESUMO
As transformações oriundas pós-revolução industrial seguem ecoando em nossa sociedade, permitindo avanços na área de tecnologia, produção e consumo de produtos em diferentes segmentos, em especial o da moda. Diante disto, o presente artigo propõe compreender, de forma inicial e conceitual, a utilização do espaço Fashion lab por designers autorais de moda. Considera-se que o uso desse laboratório pode qualificar o processo de inovação durante a produção de novos produtos. Neste trabalho, utilizou-se a pesquisa básica com abordagem qualitativa descritiva e a fundamentação teórica contempla os conceitos de inovação, fab lab, Fashion lab e design autoral. Por fim, os resultados da pesquisa indicam que os princípios de compartilhamento, experimentação e prototipação corroboram para a inovação no design autoral de moda em fashion labs.
\end{abstract}

Palavras-chave: Fashion lab. Design autoral. Inovação. 


\title{
El laboratorio de moda como factor de innovación en el diseño de moda de autor
}

\begin{abstract}
O
Las transformaciones derivadas de la revolución postindustrial continúan resonando en nuestra sociedad, permitiendo avances en el área de tecnología, producción y consumo de productos en diferentes segmentos, especialmente moda. Ante esto, este artículo se propone entender, de forma inicial y conceptual, el uso del espacio del laboratorio de moda por parte de los diseñadores de moda. Se considera que el uso de este laboratorio puede calificar el proceso de innovación durante la producción de nuevos productos. En este trabajo se utilizó la investigación básica con un enfoque descriptivo cualitativo y la base teórica contempla los conceptos de innovación, fab lab, Fashion lab y diseño de autor. Finalmente, los resultados de la investigación indican que los principios de compartir, experimentación y creación de prototipos corroboran la innovación en el diseño de moda de autor en los laboratorios de moda.
\end{abstract}

Palabras clave: Laboratorio de moda. Diseño. Innovación. 


\section{INTRODUCTION}

Historically, the Industrial Revolution - which occurred in Europe in the XVIII century - brought about major changes in the logic of organizing the conception, distribution, and consumption of goods, with emphasis on the concentration of the means of production in the hands of industrial conglomerates. However, when one visualizes the last decade, one can see that the dissemination of technology, within a consolidated context of the Information Society (CASTELLS, 2009), corroborated with changes in western society, resulting in changes in the current modes of production, consumption of goods and the very management of social life.

From this context, several industries needed to remodel to follow such transformations. The fashion industry, which has historically been influenced by social changes, once again must strive to absorb the main changes that are happening, manifested in the logic of collaborative consumption, products seen as sustainable, consumers with particular desires, fast fashion versus slow fashion, open design, small-scale production, etc.

In addition to industrial changes, what is also perceived as a change in the role fulfilled by consumers: they are more attentive, more authoritarian, more daring, that is, there is the rise of consumers behaving as producers of goods and services, suggesting a new logic to produce and consume. In parallel to this, aspects such as entrepreneurship and facilitated access to new technologies set the tone for a new context, which gives rise to the emergence of the Maker Movement, which emerges as a response to the world economic crisis, underlined by a creative and knowledge, in which it gives the condition of the people to carry out with 
their own hands personal, experimental and innovative projects (ANDERSON, 2012; SILVA, 2017; SILVA; SILVEIRA, 2018). These different conceptions are done collectively or individually, without necessarily - being linked to an organization, increasingly strengthening the so-called maker culture in the social sphere.

In line with the decentralization of the means of production observed in the last decade, spaces emerge to meet the work needs of the makers, such as creative spaces or hackerspaces (ANDERSON, 2012). From this, there are the so-called fab labs that give the condition of the creative subject (FLORIDA, 2011) to explore different technologies and machinery in support of their projects, as well as being open to the public and having values supported by collaboration and experimentation. When thinking about the production of fashion, there are fashion labs, which are configured as environments that unite different technologies and machinery with fashion digital manufacturing, allowing more democratic access to the entire community.

Considering the aspects described so far, the research problem of this article is configured in: how can the fashion lab space contribute to the innovation in fashion author design? In other words, the intention of this article is to understand if the use of fashion labs by fashion designers can contribute to the innovation in the process of designing new products from the aspects and characteristics of these spaces.

The methodological steps, in terms of classification, aim at basic research, with a qualitative approach and descriptive purpose. From the point of view of technical procedures, it relies on the methodology of bibliographical revision, seeking a theoretical and conceptual articulation between the different authors in order to reach the intention of the study from the resolution of the problem previously exposed. 
In a structural way, it is necessary to define the concept of innovation according to Bertoni and Moura (2016), Handbook of Oslo (2005) and Manzini (2008), concept of authorial designer through the reflections of Baxter (2011), Sohn, Laste and Rios (2017), Parode and Scaletsky (2009) and Gonçalves (2014), concept of fab lab from the definition of Eychenne and Neves (2013), Silva and Silveira (2018), Silva (2017), Anderson (2012), (2018) and the concept of fashion lab from the perspective of the Textile Academy (2018), Bastos (2014) and the TCBL (2018). Afterward, conceptual research will be carried out in which it is sought to understand the importance of the characteristics of space from fashion lab to designers of fashion for innovation from the principles of sharing, experimentation, and prototyping.

Finally, this reflection is extremely relevant for investigating technological, industrial, economic, and structural changes, among others, for the fashion sector. In addition, when defining the use of fashion labs by the designers, the changes in the way of thinking and producing consumer goods with more exclusive bias are analyzed, going to the opposite side of the saturation and homogenization of supply and consumption fashion from the phenomenon of fast fashion.

\section{METHODOLOGICAL STEPS}

In this topic, this article is classified in scientific terms through the use of methods, techniques, and procedures, since the scientific methodology "constitutes the way of building the scientific method" (SILVEIRA, 2018, p. 13). In this way, the methodological steps comprise research with a basic purpose. This is because "aims to generate new knowledge useful for the advancement of science without 
predicted practical application" (SILVEIRA, 2018, p. 15), through the articulation of authors who research the themes of innovation, fashion labs, and author design.

From the point of view of the problem approach, it is classified as qualitative. According to Gil (2008, p.15), the qualitative approach "considers that there is a dynamic between the real world and the subject", that is, we seek an interpretation and construction of meanings from the data obtained throughout the study. From the point of view of the objectives sought, they are considered descriptive, since this type "aims to describe the relations between variables" (SILVEIRA, 2018, p. 17), working with the description of some fact or phenomenon.

Finally, from the point of view of technical proceeding, the research is based on the methodology of bibliographical revision, seeking a theoretical and conceptual articulation between the different authors in order to respond to the proposed intention. According to Lakatos and Marconi (2017), this strategy allows us to get in touch with every published theoretical reference, whether in monographs, theses, books or even in audiovisual materials. That is, by reviewing the bibliography, one can understand what has already been researched, the main conclusions and opportunities for new approaches on the same subject.

According to Stumpf (2010, p. 51), this methodology can be understood from the points of view: broad and restricted sense. In a broad sense, this methodological design is configured as the moment to visualize the research in a global way, understanding the beginning, the middle and the end. That is, you are planning what to do, how to do it and what concepts to use. Finally, the synthesis of everything that is necessary to develop the research proposal through an 
academic text is carried out, with the inclusion of the researcher's ideas and interpretations.

In a restricted sense, Stumpf (2010, p. 51) argues that it is important to focus more intensively on theories, authors, and approaches that contribute objectively to solving the established problem. Through summaries and files, we obtain a theoretical basis for argumentation and reflection, and it is possible to agree or disagree with the data collected during the methodological process.

In a structural approach, after reviewing the concepts of innovation, fab lab, fashion lab, and author design, the characteristics of fashion laboratories are understood through a synthesis materialized in three principles: sharing, experimentation, and prototyping. From these, it is proposed a conceptual triangulation with the types of innovation established by the Oslo Manual (2005), in order to understand how fashion lab can contribute to the innovation in the process of authorial fashion design with a theoretical approach.

\section{THEORETICAL FOUNDATION}

\subsection{Innovation}

The concept of innovation is interdisciplinary and its origin is somewhat indefinite since different areas have appropriated this term, generating own and distinct interpretations (BERTONI; MOURA, 2016). In this study, it is sought to explore some approaches of the idea of innovation, synthesizing the main characteristics of this multifaceted noun.

To think about innovation, it becomes crucial to reflect on the idea of creativity and the interlocution between these two concepts. In this sense, Hartley (2005) argues that man alone 
is creative, and Howkins (2007) points out that society has simply ceased to process information in order to use it for creativity. In addition, the author believes that our society began to value the generation of ideas, perceiving in this phenomenon a new relationship between economy and creativity, since man is making money from his ideas (HOWNKINS, 2007).

Parallel to this, the valuation of intangible assets is a recent development and is correlated with what Florida (2011) calls the diffusion of innovation. That is, knowledge and information are artifacts used to catalyze creativity; the materialization and diffusion of these ideas are called innovation, being visualized in the form of artifacts, goods, and services. In short, it is possible to emphasize that creativity is something intangible, is in the field of ideas, innovation is tangible, physical, palpable and that one moment is succeeded by the other.

Considering the purpose of this study, which is to understand how fashion labs can contribute to the innovation of products by fashion designers, it is sought to expand the concept of innovation, from the Oslo Manual (2005, p. 55) defining as:

[...] the implementation of a new or significantly improved product (good or service), or a process, or a new marketing method, or a new organizational method in business practices, workplace organization, or external relations.

From this, it is understood that the concept of innovation exists from the activities, methods, and processes undertaken in the conception of a final product/service/good. Therefore, "an innovative company is one that has implemented innovation during a period of analysis" (OSLO MANUAL, 2005, 
p. 55). Also according to the Oslo Manual (2005), there are four main types, as shown in the following table:

Table 1. Types of Innovation

\begin{tabular}{|l|l|}
\hline Types of Innovation & Definition \\
\hline Of product & $\begin{array}{l}\text { Introduction of a new good or service or improved significantly in their } \\
\text { characteristics or intended uses. This includes significant improvements } \\
\text { in technical specifications, components, and materials, embedded } \\
\text { software, ease of use, or other functional features. }\end{array}$ \\
\hline Of process & $\begin{array}{l}\text { Implementation of a new or significantly improved production or } \\
\text { distribution method. Significant changes in techniques, equipment } \\
\text { and/or software are included. }\end{array}$ \\
\hline Of marketing & $\begin{array}{l}\text { Implementation of a new marketing method with significant changes in } \\
\text { product design or packaging, product placement, promotion or pricing. }\end{array}$ \\
\hline Organizational & $\begin{array}{l}\text { Implementation of a new organizational method in the company's } \\
\text { business practices, in the organization of its workplace or in its external } \\
\text { relations. }\end{array}$ \\
\hline
\end{tabular}

Source: OLSO MANUAL (2005, p. 57-61), adapted by Silva (2018, p. 96).

Contrary to common sense truths, in which they assert that an innovative product or process must be revolutionary or totally disruptive, it is possible to understand that this concept can be translated into the improvement of a product, process, service, space. With specific focus, product innovations "may use new knowledge or technologies, or may be based on new uses or combinations of existing knowledge or technologies" (OSLO MANUAL, 2005, p. 57). Therefore, it is possible to understand that innovations of the incremental type (small modifications throughout the product design process), or of the radical type (involving total alterations a compared to previously produced products) can be proposed.

Among the many possibilities of thinking and doing innovation, there is a specific type that manifests itself in the face of the complexity of the world: social innovation. According to Manzini (2008, p. 61-62), the term refers to a new behavior that individuals and communities adapt in the face of their local problems and are guided by 'bottom-up' 
organizational processes rather than those low'", demonstrating a new way of articulating all the subjects involved. Besides that,

[...] designers have the mission of facilitating the convergence of different partners around shared ideas and potential solutions. This type of activity requires a number of new design skills: promoting collaboration between different social actors (local communities and firms, institutions and research centers); participate in the construction of shared views and scenarios; and combine existing products and services to support the specific creative community with which they collaborate (MANZINI, 2008, p. 28).

Here, two main relationships are established between the process of innovation and social design. The first is that design activity is seen as mediating between technology, social problems and the generation of ideas for innovation (be it products, processes, marketing or organizations). The second is seen insofar as the concept of social design looks at a social - local sphere in the search for innovative processes, approaching subjects involved in high or low degree with the problem to be solved through a methodology proposed in six stages: inspiration, proposals, prototyping, support, diffusion and systemic change (HUGO; MOURA, 2015).

In this study, in synthesis, the innovation process, to occur in practice, has as its presupposition the creativity that can be seen in four types (product, process, marketing, organization) and can be used to solve local problems from the design Social. The following is a reflection on the concept of authoring design, which is underlined as important for further discussion. 


\subsection{Authorial design}

Due to global industrialization and the democratization of access to consumer goods for a large part of the population, consumers now have the power to choose at the moment of consumption. As Baxter (2011, p. 17) states, "a manufacturer who is not able to move quickly enough in this new business world can be seriously compromised," contrasting with past times of money shortages and product choices, and services.

In this new paradigm, it is emphasized that the development of new products by brands, factories, and designers is not an easy task. This "requires careful research, careful planning, and, more importantly, the use of systematic methods" (BAXTER, 2011, p. 19). Through this, methodologies for product creation need an interdisciplinary approach, organization, and practice, dialoguing with aspects of marketing, engineering, aesthetics, technology, psychology, among others. In this sense, the ones involved in product development and their respective ones are presented below:

Table 2. Actors involved in product development

\begin{tabular}{|l|l|}
\hline Actors & Desires \\
\hline Consumers & They want better news and products at reasonable prices. \\
\hline Sellers & They want differentiation and competitive advantages. \\
\hline Production engineers & $\begin{array}{l}\text { They want simplicity in manufacturing and ease of } \\
\text { assembly. }\end{array}$ \\
\hline Designers & They want to try new materials, processes, and solutions. \\
\hline Business executive & $\begin{array}{l}\text { They want some investments and a quick return on } \\
\text { capital. }\end{array}$ \\
\hline
\end{tabular}

Source: BAXTER (2011, p. 11), adapted by the authors.

To line up the stakeholders elucidated in Table 2 with the focus of this research, two observations are important. The first considers consumers that belong to the universe of 
author consumption; this means that they are consumers who, in addition to wanting better products and news at reasonable prices, are looking for relational, creative, cultural and visual products (MORACE, 2018). The second concerns designers who design for an authorial manufacture; therefore, do not belong to activities focused on corporate design, "not allowing the designer's work to have such free results" (SOHN; LASTE; RIOS, 2017); in this sense, the scope of the study understands activities and products developed through the authorial design.

In this way, authorial design can be seen as an activity that manifests itself in the face of a post-industrial society, offering products that are saturated and massified culturally and aesthetically (SOHN; LASTE; RIOS, 2017). That is, corresponding to a man's desire to distinguish himself through the purchase of goods (whether in the transport, clothing, leisure, home ...) segment, the authorial consumer subjects may transgress and temporarily break the rules of mass society (MORACE, 2018, GONÇALVES, 2014).

According to Gonçalves (2014, p. 53), "authorial design is loaded with meanings imposed on the artifacts by the creator, and is configured, as an agent of new values." This goal is achieved by small-scale production with unique characteristics, since "author design serves to produce sensations in bodies from objects as it serves to distinguish them through symbolic charges that are aggregated, projecting them to the plane of social relations "(PARODE, SCALETSKY, 2009, p. 97), which implies a differentiated and sometimes strategic practice in the face of new consumption habits.

Also according to Sohn, Laste, and Rios (2017, p. 102), 
perspective regarding the supply and consumption of products and services. Being linked to the exclusive production, close to the characteristics of the artwork. The authorial designer can be considered an artist who constantly seeks innovation and generally always produces in small quantities, focusing on a specific niche of the market.

In this sense, it is understood that the authorial designer is seen as an agent of new values, since in designing his creations, he breaks with the homogeneous logic of the available products, either through the use of a new material, own creative process, small-scale production or even attending any needs of a consumer profile is not serviced by major brands.

Finally, the author's understanding of the fashion and clothing sector is registered. In this case, the professional and the activity are also seen as mediators (GONÇALVEZ, 2014, p. 59) for new symbolic meanings, since the products are the results of subjective and social experiments, implying in the dialogue between the author's design with other cultural references and consumer behavior. Next, the third concept (fab labs), perceived as important for later analysis, is discussed.

\subsection{Fabrication laboratories - fab labs}

The way to understand the work, along with their spaces used to meet the employment workshops, suffered several transformations over the past two decades. According to Silva and Silveira (2018, p. 132), aspects such as technology, the incentive to entrepreneurship and the emergence of the culture maker are shaping new ways of thinking about work and its environments. 
In this sense, new features of contemporary spaces of product and service design are underlined. Anderson (2012) cites as examples the creative spaces or hackerspaces, designed from Culture Maker, as spaces for innovation, in which ordinary people can make use of technology to design platforms, products, services, and solutions through the sharing of ideas, experiences, and creativity.

These spaces, perceived as a reflection of a new social paradigm, are strengthened every day with access to the internet, the democratization of technology, sharing of information and betting on experimental methodologies as a condition of production. Teixeira, Almeida, and Ferreira (2016, p. 6) define these spaces from the nomenclature of innovation habitats since they are "differentiated spaces, propitious for innovations to occur since they are a locus of sharing information and knowledge, forming networking, and minimize risks and maximize results. " That is, new space formats to be used to work creatively, innovatively, technologically and experimentally expand the possibilities for creative subjects such as designers, students, professionals, and researchers.

Considering new possibilities and different environments, Jackson (2018) deals with the specific category called coworking. This concept refers to both the physical space in which different people use and the idea of subjects sharing ideas, experiences, and feedback to work collectively in an intangible approach, the lack of physical space.

In this way, while some spaces are understood as coworking seen by physical characteristics, for example, fab lab, others are understood as such by the intangible characteristic of the union and connection of people who work based on the exchange of ideas, for example, the coffee shop. Silva and Silveira (2018, p.135) emphasize that in these two 
possibilities there is the development of innovative projects, motivated in the politics of sharing of ideas and experiences since this "represents the action of the people on the geographical space by constituting the space social for creativity ".

Fab lab is seen as a space of innovation in which it is possible to find new ways of working and using the respective space. This occurs insofar as this place has the characteristics of a coworking, is guided by the logic of sharing ideas, encouraged by the essence of creativity and structured from technological machinery. Therefore, according to Eychenne and Neves (2013), one can understand a fab lab (or manufacturing laboratory) as a platform for rapid prototyping of physical objects, that is, using specific machinery and technical support, it is feasible to put into practice projects personal or collaborative. The fab labs are inserted into a worldwide network that has almost two hundred laboratories.

The worldwide network, called Fab Foundation, is a nonprofit organization that was created at the Massachusetts Institute of Technology (MIT) Center for Bits and Atoms (CBA) in 2009. According to Eychenne and Neves (2013), a fab lab is designed for professionals, students and researchers to develop different projects with democratic access to space and with low cost. These laboratories are formed by sets of professional-level numerical control machines. In other words, vinyl cutting machines for flexible circuit manufacturing, laser cutting machine used in the production of (bi or three dimensional) structures, high-resolution milling machines and 3D printers are examples of machines for the physical composition of a fab lab (EYCHENNE, NEVES, 2013).

To be viable breeding projects developed in different fab labs, there is a protocol process, machinery, and guidelines established by the Fab Lab Foundation. Thus, "the standard 
number of machines per numeric command common to the different Fab Labs allows replicating processes developed in any laboratory, regardless of their location" (EYCHENNE, NEVES, 2013, p. 12), which facilitates the connection between different users worldwide.

As for what can be developed in a fab lab, the possibilities are manifold. It is possible to develop personal and collective projects, solutions that benefit a specific community, development of prototypes to be sold/reproduced later, among others. As Silva and Silveira point out (2018, p. 137), "these developed projects can be sold or protected by copyright, and the process and techniques must be made available so that other users can use them in their projects."

In this sense, it is possible to synthesize that the purpose of a fab lab is to generate innovation for social benefit. As a result, these laboratories are created on the basis of democratic access to space, technical assistance to users by qualified professionals, and the encouragement to share the results there developed with other people.

\subsection{Fashion laboratories - fashion labs}

Similar to the fab labs, and based on the phenomenon of the decentralization of the large and traditional industry, the so-called fashion laboratories - fashion labs for the fashion sector. These spaces understood as fashion and clothing manufacturing laboratories offer technology, digital fabrication, machinery and an atmosphere conducive to innovation. According to Bastos (2014), a fashion lab can also be called a textile lab and offers democratic access to those interested in making use of this space, illustrating the changes that the fashion industry is going through and demonstrating how it is fitting. In this study, the nomenclature of the textile 
lab is used as a synonym of fashion lab and is characterized as the space of interest to understand the idea of innovation.

Looking at fashion trends and the current panorama, the need to develop ever more innovative products in both aesthetic and technological terms is evident, as well as to review methods and processes, both in the context of workshops (more artisanal and exclusive production) and industry (large-scale production) (BASTOS, 2014, p. 4).

In this way, it can be seen that the fashion industry strives to adapt to new consumer needs, to dialogue with different technologies and to understand new patterns of behavior of society as a whole. And as already mentioned above,

\begin{abstract}
Rapid prototyping and the emergence of alternative spaces, such as Fab Labs' international network, favor the sharing of ideas, projects, and experiences and also foster movements that propose an alternative direction to mass production and mass culture, presenting possibilities for a more exclusive production (BASTOS, 2014, p. 4).
\end{abstract}

Consequently, the ideas sharing features, the democratization of access to these spaces and experimentation as a production condition define these spaces. It should be noted that the approach between product conception and the digital/technological universe and its relation to designers has given rise to new forms of work since today these professionals can be connected anywhere in the world to design their products as contextualized by Silva (2017) previously.

Still relating the fashion to the fab labs, in 2014, the world network of laboratories mapped 267 spaces in operation; of these, only $16 \%$ were developing projects related to fashion (BASTOS, 2014, p. 110). That is, although these labs offer machinery and technology, the fashion industry is seen as an 
area that is taking a long time to look at - compared to such industries as engineering, architecture, and biology.

Gwilt (2014) and Fletcher (2008) comment that the creation of collaborative environments for the manufacture of clothing and fashion goods is an alternative to serial production as a result of fast fashion, in addition to making use of digital manufacturing methods. In this context, Bastos (2014) mentions that these spaces can be called fashion labs or textile labs.

In relation to the Brazilian scenario, the supply and demand of such spaces are still small. In São Paulo there is LabFashion and "Ateliê Vivo", in Porto Alegre there is the "Clube de Costura Livre" and Blumenau there is the "Fashion Lab - coletivo criativo". In this sense, it is pointed out that the appearance of such spaces for fashion is a result of the search for professionals and some organizations against the industrial overproduction of fashion through collaborative thinking, use of new technologies and non-homogenous production (such as industry of fast fashion). It is therefore within this context that the TCBL, described as a group of different companies, consultants, laboratories of innovation and technology with a view to motivating the transformations in the current scenario of the textile/fashion factories and industries, was created by the European Union in 2015 (TCBL, 2018).

According to the TCBL platform, laboratories that offer technology, machinery, and infrastructure for small-scale production, use of technology to solve different problems, and the sharing and connection of ideas play a key role in the TCBL chair. In this way, innovation, experimentation, and entrepreneurship can be materialized (TCBL, 2018).

In a pragmatic way, to understand the space of a fashion lab, part of the protocol elaborated by MIT that designs a 
fashion lab; subsequently, it includes machinery and infrastructure necessary to produce fashion. According to the TCBL and the Textile Academy (2018), fashion machines need straight stitching, overlock, and knitting, bio laboratory material, material for fabric circuits such as lines and conductive fabrics, software for developing projects and basic sewing materials (scissors, threads, fabrics, rulers...).

Despite the different nomenclatures, this research proposes the adoption of the term fashion lab to refer to spaces understood as laboratories where it is possible to think and fashion, to use equipment that is found in fab labs (3D printer, milling machine ...) and equipment clothing and fashion products (sewing machine, overlock, fabrics, lines...). Finally, in a fashion lab, it is possible to produce products on a small scale, exclusive and with innovative aspects (either by the use of a specific technology or by the solution found for a problem through experimentation).

\section{FASHION LABS INNOVATION PRINCIPLES}

As previously seen, the so-called fashion lab environments are built with specific machinery to carry out collective or individual projects for the apparel and fashion sector. Sequentially, they come from the so-called fab labs, have democratic access to different subjects (professionals, students, researchers), are designed with the intention of facilitating and boosting collaboration, sharing, prototyping of goods and processes of creativity and innovation.

In this sense, it is proposed the synthesis of three main principles of a fashion lab to think the innovation considered relevant throughout the study: (a) sharing, experimentation and (c) prototyping. From now on, each principle is explored individually, understanding and arguing 
how it is possible to think innovation for the fashion designer from each one.

\subsection{Sharing principle}

The act of sharing, according to authors who research fab labs and fashion labs, is important since in developing projects in these spaces, it happens to exchange ideas with other users about their work and others. From this, resulting from the act of communicating, the actors involved in the authorial design, for example, can contribute to specific know-how and expertise (EYCHENNE, NEVES, 2013). In addition, the environment as a whole is shared. This means that through the democratic access of different students, researchers and professionals, the exchange of feedbacks, the resolution of doubts by those who do not have in-depth knowledge in a specific machinery or technology, the construction of networking and the exchange of different experiences (SILVA; SILVEIRA, 2018; SILVA, 2017).

Finally, it is understood that the principle of sharing ideas, methods, projects, and feedback by users of fashion labs is a relevant value when thinking about innovation in authoring design. This is because it is possible to qualify product designs developed in these spaces, it is possible to better understand the use of different technologies to be inserted in the design process and find new looks for market demands, new behaviors, and trends from the collaboration between the subjects that make use of this environment. 


\subsection{Experimentation principle}

Experimentation as a condition in the process of authorial design in fashion labs is the second principle explored. This is because the idea of experimenting is also an important value in these environments, through the knowledge and discovery of new machinery and technologies in practical methodological approaches, the experimental use of space and the flexible management of the team involved in the project. That is, experimentation is a strong feature of fashion labs.

Thus, the action of experimentation approximates authorial design insofar as this design practice is done in a non-sectorized and traditional way, as in large factories, for example. Thus, even with a professional's own method, fashion lab allows the experimentation of new processes, small scale, and exclusive production, the use, and testing of different materials throughout the development of a product, resulting in the qualification and improvement of the project (GONÇALVEZ, 2014).

In view of the above, it is noted that the practice of experimentation has a significant value when thinking about innovation since there is the deconstruction of the meaning of error; in this approach, the error is viewed as a means of arriving at new solutions to different problems in a creative process through experimentation. This does not mean disruptive innovations around a product, but rather adaptations, improvements, and incremental discoveries during the fashion authoring process. 


\subsection{Prototyping principle}

The last principle discussed is prototyping. This is in line with the remarkable characteristic of laboratories: to elaborate, in practice, the idea of the user through the manufacture of prototypes and mockups. In this sense, fashion labs offer 3D printers, milling machines, specific sewing machines precisely to be feasible to design a product, even in an experimental way, at a low cost and fast way (OLIVEIRA, 2016).

Therefore, unlike other creative spaces and innovation, here it is feasible to literally come up with an idea in the head and get out of the way with a materialized product. This brings advantages to the user maker since this process detects possible faults in their process and product with ease allows the error and elaborate different solutions to specific problems (TCBL, 2018; BASTOS, 2014). In addition, it is feasible to prototype from the product belonging to the final graduation work, materialize some solution to improve the usability of some item of clothing and even contribute in the process of authorial fashion design.

Therefore, it is emphasized that the principle of prototyping corresponds to an important moment in the design of fashion authored in fashion labs, since this facilitates the process of product improvement, adaptation of texture, shape, and size, it is added the digital manufacture for fashion products and explore new solutions at a reduced cost to and by the designer. 


\subsection{Triangulation}

At this point, the synthesis of the principles that corroborate for innovation present in fashion labs that can be used by fashionable designers in Figure 1 is demonstrated. After reflecting on the principles individually, the three are merged in order to better understand the reasons for using a fashion designer from fashion labs seeking innovation.

Figure 1. Triangulation of principles for innovation

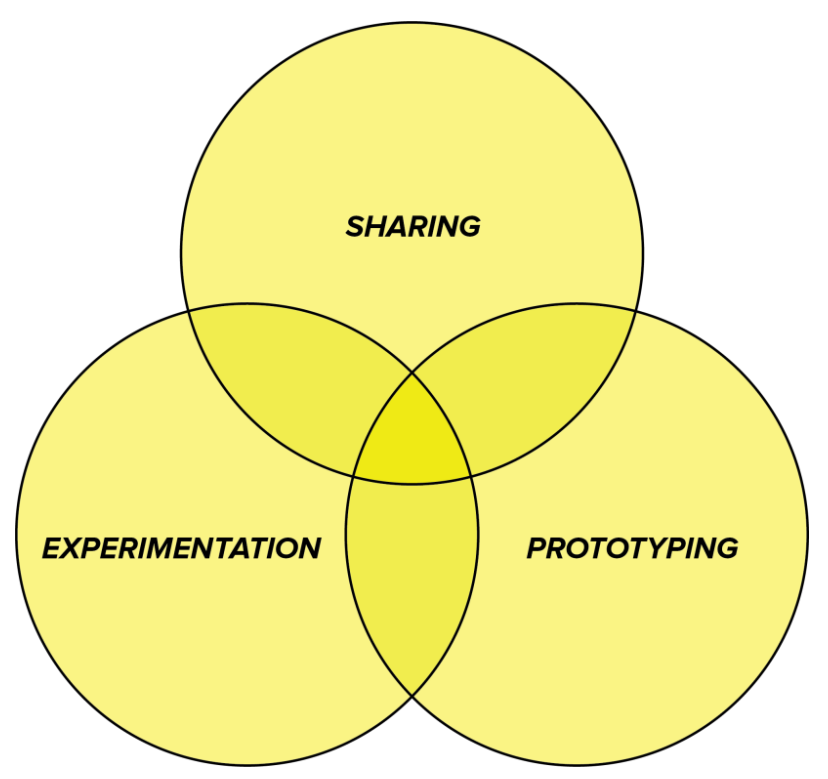

Source: prepared by the authors (2019).

It should be noted that, to a greater or lesser extent, it is possible to correlate the principles with the innovation categories addressed by the Oslo Manual (2005). In this way, the product innovation can be motivated by the experimentation of new materials, the sharing of feedback with other professionals and the prototyping of the mockup of a fashion accessory by the digital manufacture. Process innovation can be influenced by the experimentation of a new 
design methodology and the sharing of the process of elaboration of a product between different fashion labs.

In marketing innovation, it is possible to visualize the sharing of ideas relating to a specific niche of consumers, experimentation in designing a new item of clothing through co-creation and prototyping of different test article choices with particular audiences. Finally, in organizational innovation, space is shared with different users who have multiple knowledge and if they experience different ways of managing the people involved in the process.

Through this triangulation, it is noticed that some principles are not contemplated by all types of innovation, precisely because this synthesis is the result of an initial reflection on the subject. And undoubtedly, the hypotheses here versed may not happen in practice, which leads to recovering what was emphasized in the topic methodology: this study has a theoretical approach and applied research can diagnose different situations.

In addition, observing the triangulation of principles for innovation, it is understood that innovation happens in different degrees, which is directly proportional to the number of principles considered during the development of a fashion product through authoring design. That is, the greater the number of principles present, the greater the intensity of innovation during the process carried out within the fashion lab.

This means that by relying on the principle of prototyping, leaving aside sharing and experimentation, the authordesigner will have an innovative process of low intensity in the final result. In the opposite sense, if the designer makes use of the three principles during his process, it is concluded that his process will have reached a high intensity of innovation. In synthesis, at the intersection of the three principles (central 
part of the triangulation) is the greater degree of innovation, highlighting the principles addressed in this specific study, in the authorial fashion design in the fashion lab environment.

\section{FINAL CONSIDERATIONS}

By way of final considerations, it is understood that fashion labs are seen as spaces of innovation to think and fashion. They are environments designed with machinery and technology for rapid prototyping of objectives, specific machines for sewing and supported in guidelines such as collaboration, creativity and democratic access of society. In addition, after the proposed discussion, it is possible to infer that these environments can contribute to innovation in the process of authorial fashion design from three principles: sharing, experimentation, and prototyping.

In making the triangulation of the synthesized principles, it was found that they can corroborate and encourage, to a greater or lesser extent, the four types of innovations proposed by the Oslo Manual. This happens to the extent that the principle of sharing can be seen in product, process, marketing, and organizational innovation; the principle of experimentation can be seen in product, process, marketing, and organizational innovation; and the principle of prototyping can be seen in product and marketing innovation.

In addition, it is reflexively verified that the degree of innovation that can be achieved during the author design process within these spaces is directly proportional to the quantity and quality of the principles considered. Therefore, it is concluded that when designing a fashion product using the author design approach, and using experimentation, sharing and prototyping, there will be a greater innovation intensity in the final result. 
Also, based on the assumption that fashion authoring is a process that generates products with unique characteristics, differentiated and non-homogeneous design (as in slow fashion), it is concluded that the use of these laboratories brings different advantages to the professionals of fashion. Among them, it stimulates the competitive differential of designers for innovation, strengthens small brands of fashion and clothing and encourages new methodologies of thinking and making fashion authorial design.

It should be noted that the proposal and development of this study are of a purely theoretical nature, and results can be found different from those presented in research with an applied purpose that deals with innovation in fashion laboratories. Finally, there is no attempt to heal or exhaust concepts and research on the subject, since this is initial research. Therefore, it is indicated for future work the validation of the principles that corroborate for innovation discussed in this basic research, using case studies or interviews with fashion designers who make use of these spaces.

\section{REFERENCES}

ANDERSON, C. Makers: a nova Revolução Industrial. São Paulo: Elsevier Campus, 2012.

BAXTER, M. Projeto de produto: guia prático para o design de novos produtos. 3. ed. São Paulo: E. Blucher, 2011.

BASTOS, V. F. Moda e Fabricação Digital em um contexto Fab lab: equipamentos, métodos e processos para o desenvolvimento de produtos. Dissertação (Mestrado em Design) - Universidade Federal de Pernambuco - Centro de Artes e Comunicação Programa de Pós-graduação em Design. Recife, p. 153. 2014.

BERTONI, C.; MOURA, H. Por que a economia criativa é sinônimo de inovação? In: Indústrias criativas [recurso eletrônico] / organizadores Cristiano Max Pereira Pinheiro, Maurício Barth - Novo Hamburgo: Feevale, 2016.

CASTELLS, M. A Sociedade em rede. 12. ed. São Paulo: Paz e Terra, 2009. 
EYCHENNE, F.; NEVES, H. FAB LAB: a vanguarda da nova revolução industrial. São Paulo: Editorial FabLab Brasil, 2013.

FLETCHER, K. Sustainable Fashion and textiles: Design Journeys. Londres: Sterling. 2008.

FLORIDA, R. A ascensão da classe criativa. Porto Alegre: L\&PM, 2011.

GIL, A. C. Métodos e técnicas de pesquisa social. 5. ed. São Paulo: Atlas, 2008.

GonçALVES, A. S. Q. Criação Autoral Na Perspectiva Do Design Estratégico: uma análise de projetos acadêmicos de moda. Dissertação (Programa de Pós-graduação em Design). Universidade do Vale do Rio dos Sinos, 2014.

GWILT, A. A Practical Guide to Sustainable Fashion. 2014.

HARTLEY, J. Creative industries. Malden, MA, Oxford e Victoria: Blackwell, 2005.

HOWKINS, J. The creative economy: how people make Money from ideas. 2nd ed. London: Penguin Books, 2007.

HUGO, M.; MOURA, H. A contribuição do design para a inovação social sustentável. Anais... XI Semana de Extensão, Pesquisa e Pósgraduação - SEPesq. Centro Universitário Ritter dos Reis, 2015. Disponível em: https://www.uniritter.edu.br/xiii-sepesq. Acesso em: 10 nov. 2018.

JACKSON, K. Make space for others. Disponível em: http://www.makingspaceforothers.com. Acesso em: 20 nov. 2018.

MANZINI, E. Design para inovação social e sustentabilidade: comunidades criativas, organizações colaborativas e novas redes projetuais. Rio de Janeiro: E-papers, 2008.

MARCONI, M. de A.; LAKATOS, E. M. Fundamentos de Metodologia Científica. $8^{\circ}$ ed. São Paulo: Atlas, 2017.

MORACE, F. Consumo autoral: os novos núcleos geracionais. Francesco Morace; $4^{\circ}$ ed. São Paulo: Estação das Letras e Cores Editora, 2018.

MANUAL DE OSLO: diretrizes para a coleta e interpretação de dados sobre inovação tecnológica. Publicado pela FINEP (Financiadora de Estudos e Projetos), $3^{\circ}$ ed. 2006.

OLIVEIRA, D. J. L. O uso da Prototipagem e Fabricação Digital no ambiente Fab lab. Dissertação (Mestrado em Design) Programa de Pós-Graduação em Design, Faculdade de Engenharia. Universidade Federal do Rio Grande do Sul, Porto Alegre, 2016.

PARODE, F. P.; SCALETSKY, C. C. Design de autor: uma outra comunicação desafiando cultura e mídia global. Journal GHREBH, v. 1, n.13, 2009.

SILVA, M. G. e. Ambientes de inovação para a Indústria Criativa. In: Processos e práticas nas atividades criativas e culturais: reflexões e interfaces da comunicação e da indústria criativa/ Marcela Guimarães e Silva, Renata Corrêa Coutinho (org.). Santiago: Oliveira Books, 2017. 
SILVA, M. G.; SILVEIRA, A. C. M. Das garagens às cidades: espaços sociais para a indústria criativa. In: Comunicação e Indústria Criativa: políticas, teorias e estratégias/ organizadores Joel Felipe Guindani e Marcela Guimarães e Silva. Jaguarão, RS: CLAEC, 2018.

SILVEIRA, I. Procedimentos Metodológicos de Pesquisa: ciência e conhecimento. Programa de Pós-graduação em Moda, UDESC, 2018.

SOHN, A. P. L.; LASTE, L. N. B.; RIOS, M. A. T. Design autoral: um estudo na região do Vale do Itajaí. In: e-Revista LOGO, v. 6, n. 3, UFSC, $2017 . \quad$ Disponível em: http://incubadora.periodicos.ufsc.br/index.php/eRevistaLOGO/artic le/view/4922. Acesso em: 18 nov. 2018.

STUMPF, I. R. C. Pesquisa bibliográfica. In: DUARTE, Jorge; BARROS, Antonio (Orgs.). Métodos e técnicas de pesquisa em comunicação. 2. ed. São Paulo: Atlas, 2010.

TCBL. Labs. Disponível em: https://tcbl.eu/labs. Acesso em: 25 out. 2018.

TEIXEIRA, C. S.; ALMEIDA, C. G.; FERREIRA, M. C. Z. Habitats de Inovação: alinhamento conceitual. Florianópolis: Perse, 2016.

TEXTILE ACADEMY. About Fabriacademy. Disponível em: http://textile-academy.org/about/. Acesso em: 12 out. 2018. 